\title{
Article \\ Construction Activity as an Element of Suburban Zone Development
}

\author{
Donata Wysocka, Jadwiga Biegańska (D) and Elżbieta Grzelak-Kostulska *(D) \\ Department of Urban Studies and Regional Development, Faculty of Earth Sciences and Spatial Management, \\ Nicolaus Copernicus University, Lwowska 1,87-100 Toruń, Poland; 293788@stud.umk.pl (D.W.); \\ jadwigab@umk.pl (J.B.) \\ * Correspondence: grzelak@umk.pl
}

Citation: Wysocka, D.; Biegańska, J.; Grzelak-Kostulska, E. Construction Activity as an Element of Suburban Zone Development. Land 2021, 10, 1229. https://doi.org/10.3390/ land10111229

Academic Editor: Fabrizio Battisti

Received: 27 September 2021

Accepted: 9 November 2021

Published: 11 November 2021

Publisher's Note: MDPI stays neutral with regard to jurisdictional claims in published maps and institutional affiliations.

Copyright: (c) 2021 by the authors. Licensee MDPI, Basel, Switzerland. This article is an open access article distributed under the terms and conditions of the Creative Commons Attribution (CC BY) license (https:/ / creativecommons.org/licenses/by/ $4.0 /)$.

\begin{abstract}
The dynamic process of suburbanisation in the countries of Central and Eastern Europe, including Poland, causes changes in the scale of the construction activity, mainly in the communes surrounding large cities. Although, in Poland, suburbanisation processes were initiated with the system transformation, and the first spatial planning law was adopted only in 1994. In addition, building permits were issued in an unplanned manner, regardless of future consequences. As a result, housing development, despite its high intensity in suburban zones, is dispersed and chaotic. The aim of this study is to juxtapose the construction activity with the guidelines governing this sphere contained in strategic and planning documents, with the example of the suburbs of Torun. On the basis of the statistical data, and the planning and strategic documents at different levels, it is shown that construction activity, because of its interference in space, is indeed an important element shaping suburban zone development; there is a burning need for the appropriate, i.e., sustainable and long-term, planning of this process. This planning may be boosted by considering the potential development scenarios for the analysed communes belonging to the Torun suburban area set out in this study.
\end{abstract}

Keywords: Poland; suburbs; planning; construction

\section{Introduction}

The dynamic process of urbanisation, which has been progressing worldwide, is contributing to the transformation of the contemporary settlement network. For a very long time, this phenomenon and process were identified with urban development $[1,2]$. From the turn of the 20th century, scholars began to refer to urbanisation also when considering formally rural areas, paying attention, in this context, primarily to the suburban zones forming around cities, especially large ones [3-10]. Self-evidently, the suburban zone began forming with the suburbanisation phase, but much more advanced transformations were also observed in the subsequent phases of deurbanisation and reurbanisation [11]. Because of the original rural character of the suburban zones and the increased influence of the city, both urban and rural patterns permeate the area $[12,13]$. This causes difficulties in defining the boundaries, both of the city and of the typical rural area [14-17]. In addition, the size and nature of the suburban zone itself is determined by additional factors, including the size of the city that generates the zone, and the level of the socioeconomic development of the region in which the zone is located [18]. As a result, suburban zones form separate settlement structures with high internal diversity.

Regardless of its size and degree of differentiation, the suburban zone is characterised by an increased intensity in construction activity [19]. This is due to the fact that the formation of suburban zones is associated with a consistent influx of the population [20], and this forces an increase in the construction activity. Unfortunately, the rapid inflow of people to suburban zones, especially recorded in the last quarter of a century in the countries of Central and Eastern Europe (CEE) [21-24], including Poland, is only rarely accompanied 
by the adequate planning of housing development $[25,26]$. This is a problematic issue, as the residential function is one of the core functions in the suburban zone. Although, in Poland, suburbanization processes were initiated with the system transition, the first spatial planning law was adopted only in 1994 [27]. In addition, building permits were issued in an unplanned manner, regardless of future consequences. As a result, housing development, despite its high intensity in suburban zones, is dispersed and chaotic [28].

In the context of the above arguments, the aim of this study is to juxtapose construction activity (insofar as it relates to residential development) with the guidelines governing this sphere contained in strategic and planning documents. This will let us determine scenarios for the development of the suburban communes surrounding the city of Torun (Poland). This issue seems to be particularly important considering the lack of precise legal provisions concerning the shaping of housing development in the suburban zones in Poland, the rather liberal policy of suburban communes ${ }^{1}$ concerning the requalification of land for housing purposes, and the lack of a long-term local policy concerning the shaping of housing estates. In this study, we identify the areas potentially at risk of misdirected spatial management and, conversely, potentially well-directed ones, by analyzing the indicators of the construction activity and the conclusions stemming from strategic and planning documents. Thus, these constructed scenarios will provide the opportunity to consider different directions for change. However, it is most important to analyze the warning variants, which should be understood as warnings against the risk of entering into an undesirable development trajectory.

\section{Theoretical and Methodological Aspects of Suburban Zone Research in the Context of Construction Activity}

One of the most important processes shaping the contemporary settlement network in highly developed regions around the world, including Europe, is suburbanization [29,30]. This phenomenon and, at the same time, process, is related to people leaving the unattractive parts of cities in favor of places located in their vicinity, offering much more favorable living conditions in terms of the surroundings. Suburbanisation is seen as primarily resulting from the multidimensional process of modernisation: economic-associated with an increase in the wealth of society; technical—combined with the spread of better and better means of transport, especially individual transport; and social-associated with a change in aspirations, mainly of the middle class, to change their residential environment [31,32].

Suburbanisation is a process highly variable in time and space. In addressing this issue, we should note that the spatial scope and functions of its main product, the suburban zone, expanded significantly, first at the turn of the 20th century because of the intensive process of industrialisation [2], and then in the second half of the 20th century because of the exceptionally dynamic process of urbanisation $[29,33]$. As a result, the semantic scope of suburbs, as relatively densely built-up areas lying outside the boundaries of the central city, has become, and continues to become, wider. The expanding range of meanings is also related to the continuous technological progress and the functional specificity of the city that produces the zone [34,35].

Moreover, the variability of the suburban zone and its spatial extent are very strongly determined by the location of the central city in different parts of the world. This results from the fact that suburbanisation, understood as an exodus of city-dwellers to adjacent rural areas, first took place in the USA as early as the beginning of the 20th century $[20,36,37]$. In Western Europe, suburbanisation, defined in this way, began after World War II [38,39]. In Central and Eastern Europe, including Poland, one should speak of a significant delay in the process of suburbanisation [40], which started in this area only after the systemic transformation was launched, i.e., in the 1990s. What is particularly interesting is that, until the outbreak of World War II, cities in Central and Eastern Europe were subject to similar conditions and, therefore, transformations that were characteristic of cities in Western Europe [41]. However, the introduction of a different political system in Central and Eastern Europe after the war (communism or socialism, depending on the country), together 
with the accompanying socioeconomic changes, delayed the transformation of cities to the postindustrial phase of their development [42-44]. Therefore, in the second half of the 20th century, while suburbanisation processes were taking place in North America, Australia, and Western Europe, a specific type of urbanisation called "socialist urbanisation" was triggered in Central and Eastern Europe [45,46], stimulated mainly by industrialisation, with a centrally controlled economy and rather slow modernisation. Even in the 1960s and 1970s, when deurbanisation processes, such as counterurbanisation and ex-urbanisation, were observed in highly developed regions in the world [47,48], Central and Eastern Europe still experienced concentration processes related to the influx of people of mainly rural origin into cities $[22,23,49]$. This situation prevailed until the late 1980s. The concentration of populations in the cities of the socialist parts of Europe was mainly due to the public ownership of urban spaces and the accumulation of the populations in large housing complexes made up of blocks of flats built from large-panel concrete prefabricates, often poorly equipped, aesthetically questionable, and substandard [50]. These housing estates, located peripherally on the outskirts of the city but always within its borders, were in line with the doctrine of real socialism promoting multifamily housing [51]. Such measures meant that CEE cities were characterised by high spatial compactness and clearly defined boundaries in relation to their rural hinterlands [52].

In this region, including Poland, the beginning of the systemic transformation, which caused a number of dynamic changes, especially in the labour market and housing construction [53], triggered the transformation of the postsocialist city into a capitalist city, on the one hand, and initiated dynamically progressing suburbanisation processes on the other hand. Because of the intensity of this phenomenon, various cities in Poland, or more broadly urban regions, simultaneously experienced the processes of suburbanisation, deurbanisation, and even reurbanisation, in accordance with van den Berg's (1982) classic concept of the life cycle of an urban region $[54,55]$. This makes it possible to treat Polish suburbanisation as a broader phenomenon, combining the characteristics of both classically understood suburbanisation and deurbanisation.

When analysing transformations in suburban areas, it is necessary to pay attention to local conditions that may be crucial for the course of the suburbanisation process. One such condition is the housing deficit, estimated at 1.7 million units in 2002, and at over 1.0 million units in 2012 [56], which, since the start of the systemic transformation, has been compounded by the lack of a stable and long-term state policy on housing support [27]. Attention is also drawn to the poor housing conditions in urban large-panel prefabricated housing estates, built until the early 1990s [57]. The suburbanisation process also began under the influence of the transformation of the land ownership structure related to the possibility of private property acquisition, and much higher land rent values in the city than outside $[58,59]$. All these factors have had an impact on the dynamically progressing suburbanisation process.

The above-mentioned factors, influencing the shape and pace of Polish suburbanisation, underline the fact that the development of suburban zones is identified primarily with the residential function and, thus, is considered mainly through the prism of residential development and construction activity. This is because the formation of suburban zones is associated with a consistent influx of the population [60], and this forces an increase in the construction activity. Unfortunately, the intensive influx of people to the suburban areas in CEE countries, including Poland, has not been followed by spatial planning (cf. [61]). In Poland, for example, the first law on spatial planning was not introduced until 1994, i.e., four years after the start of the system transformation and the launch of the suburbanisation process. What are also characteristic of Polish land development at the local level is that local authorities reclassify land in a rather arbitrary manner (from agricultural to other functions, including housing); they often follow the guidelines of the study of the conditions and directions of spatial development when issuing building permits; only small portions of land are covered by Local Spatial Development Plans; and there is no effective and coordinated state policy in the field of housing development planning $[62,63]$. As a 
result, communes allocate too large areas for housing development, usually many times exceeding their needs and economic potential. Thus, suburban zones have been dotted with quite dispersed residential development, which is additionally accompanied by numerous problems related to accessing adequate accompanying infrastructure and services [64,65]. Finally, as argued by K. Heffner [66], the lack of planning in the organisation of suburban settlements is linked to a deepening lack of spatial order on the local and regional scales, the degradation of rural landscape values, and the loss of cultural identity. This is not without implications for the long-term and sustainable development of suburban zones and, thus, of entire urban regions, of which the zones are an important component.

The enormous dynamics of the suburbanisation process in Poland, not coupled with adequate spatial planning, has resulted in urban sprawl as its main form. It is usually a discontinuous, chaotic, and spontaneous process, manifested by the development of spacious suburbs that, through the expansion of housing and service infrastructure, encroach further and further into typical rural areas used for agricultural purposes [67]. Among the main features of the rural landscapes affected by urban sprawl are loose housing development (usually one-storey, much less often two-storey) and a low concentration of other types of buildings with no centre. Punctual or noncontiguous development, known as leap-frog or confetti-type urbanisation, is also an important characteristic. These are the results of locating housing developments inside agricultural or forest areas [68]. The important features of urban sprawl are its functional segregation and homogeneity, which are manifested (especially in American cities) by endless rows of similar, or even identical, detached houses, often unfenced, with a front lawn and garage [19,37]. The urbanisation of the suburban zone in the form of urban sprawl (also called suburban sprawl because of its area of influence) is usually treated as a pejorative form of urbanisation, which results in irrational spatial arrangements instead of network systems compliant with the principles of sustainable development [69-71].

\section{Research Methods and Study Area}

\subsection{Research Methods and Source of Information}

This study made use of a variety of data sources. An important element, constituting the starting point for the considerations undertaken, was a review of the literature on the theoretical and methodological aspects of suburban research in the context of construction activity. Subsequently, the authors used statistical data available at the Local Data Bank of the Central Statistical Office in Poland (LDB CSO) concerning the intensity of construction activity and the standard of housing. The data needed to carry out the analysis of construction activity concerning its intensity was established on the basis of indicators, such as: $x_{1}$-the number of permits issued for the construction of a single-family house per 10,000 inhabitants; and $x_{2}$-the number of dwellings completed per 1000 inhabitants. The elements that make up the construction activity were analysed as at the year 1999, when, in Poland, the suburbanisation process began exerting its impact; at 2009, when it reached its peak; and at 2019, to illustrate the current state of affairs in this respect.

Planning and strategic documents at different levels were a highly important source of information in this study (Figure 1). Although the study only concerned the communes making up Torun's suburban zone, higher-tier documents were also analysed with the knowledge that they underpin local law. On the national level, the authors analysed the National Spatial Development Concept 2030, at the voivodeship ${ }^{2}$ level-the KujawskoPomorskie Voivodeship Development Strategy; and at the poviat ${ }^{3}$ level-the Toruński Poviat Development Strategy. At the commune level ${ }^{4}$, which was primarily of interest to us, all strategic and planning documents were analysed, both obligatory and optional (Figure 2). The authors considered documents such as the Study of Conditions and Directions of Spatial Development (obligatory document for local governments in Poland), the Development Strategy (optional document for local governments in Poland), as well as Local Spatial Development Plans (optional document for local governments in Poland). These documents were reviewed for each commune deemed part of the suburban zone 
of Torun (Table 1). The analysis of the strategic and planning documents was based on the current versions of the documents in the individual territorial units. In each of the above-mentioned documents, special attention was paid to the construction activity in relation to suburban zones, both in terms of the current state of affairs, and the directions of its development proposed in the documents.

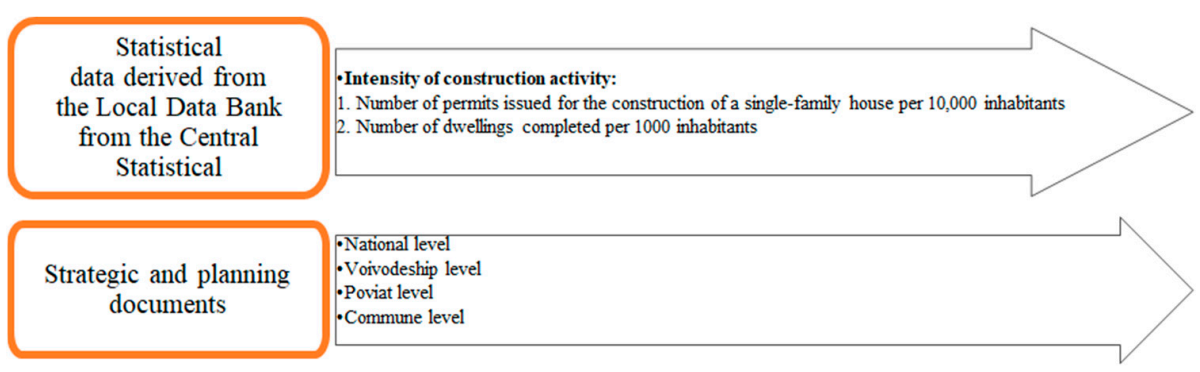

Figure 1. Source of information used in the study. Source: authors' own elaboration.

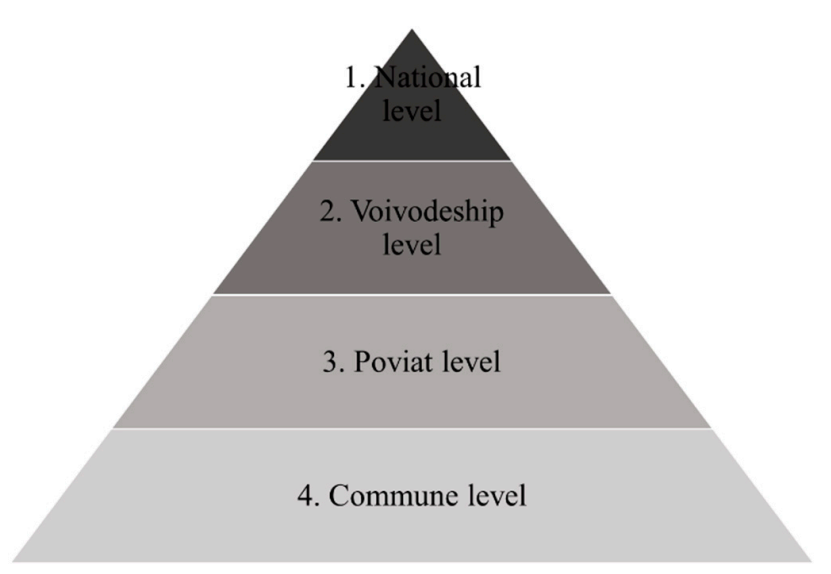

Figure 2. Scheme of the strategic and planning documents of different levels tackled in the study: 1. National level: National Spatial Development Concept 2030; 2. Voivodeship level: KujawskoPomorskie Voivodeship Development Strategy until 2030; 3. Poviat level: Toruński Poviat Development Strategy 2012-2020; 4. Commune level: obligatory and optional strategic and planning documents (specified in Table 1). Source: authors' own elaboration.

Table 1. Strategic and planning documents of the commune level considered in the study. Source: authors' own elaboration.

\begin{tabular}{|c|c|c|}
\hline \multirow{2}{*}{ Commune. } & \multicolumn{2}{|c|}{ Strategic and Planning Documents } \\
\hline & Obligatory & Optional \\
\hline Czernikowo & $\begin{array}{l}\text { Amendment to the Study of Conditions and Directions of } \\
\text { Spatial Development in Czernikowo Commune of } 30 \\
\text { September } 2013\end{array}$ & $\begin{array}{l}\text { Czernikowo Commune Development Strategy } \\
\text { until } 2020\end{array}$ \\
\hline Lubicz & $\begin{array}{l}\text { Lubicz Commune Study of Conditions and Directions of } \\
\text { Spatial Development of } 11 \text { October } 2011\end{array}$ & $\begin{array}{l}\text { Lubicz Commune Development Strategy } \\
\text { 2013-2020 }\end{array}$ \\
\hline Łubianka & $\begin{array}{c}\text { Amendment to the Study of Conditions and Directions of } \\
\text { Spatial Development in Eubianka Commune of } \\
\text { 3 September } 2014\end{array}$ & $\begin{array}{l}\text { Łubianka Commune Development Strategy } \\
\qquad 2015-2023\end{array}$ \\
\hline Łysomice & $\begin{array}{l}\text { Eysomice Commune Study of Conditions and Directions of } \\
\text { Spatial Development of } 26 \text { April } 2012\end{array}$ & $\begin{array}{l}\text { Łysomice Commune Development Strategy } \\
\text { 2018-2028 }\end{array}$ \\
\hline Obrowo & $\begin{array}{l}\text { Obrowo Commune Study of Conditions and Directions of } \\
\text { Spatial Development (Draft of Study Changes 2019-2020) }\end{array}$ & $\begin{array}{l}\text { Obrowo Commune Development Strategy } \\
\text { 2016-2023 }\end{array}$ \\
\hline Wielka Nieszawka & $\begin{array}{l}\text { Wielka Nieszawka Commune Study of Conditions and } \\
\text { Directions of Spatial Development of February } 2000\end{array}$ & $\begin{array}{l}\text { Wielka Nieszawka Commune Development } \\
\text { Strategy 2015-2025 }\end{array}$ \\
\hline Zławieś Wielka & $\begin{array}{l}\text { Zławieś Wielka Commune Study of Conditions and } \\
\text { Directions of Spatial Development of } 19 \text { October } 2011\end{array}$ & $\begin{array}{l}\text { Zławieś Wielka Commune Development } \\
\text { Strategy 2015-2023 }\end{array}$ \\
\hline
\end{tabular}




\subsection{Study Area}

The spatial scope of the study was limited to the communes deemed the suburban zone of Torun, i.e., from Toruński Poviat. Regardless of the adopted classifications and typologies of the suburban zones of Torun [72-75], the communes of Toruński Poviat are usually treated unquestionably as the suburbs of this city. The only exceptions here were the urban commune and rural commune of Chełmża, which were included in the analysis of construction activity (in the light of the LDB CSO data) and, on this basis, they were both excluded from the main part of the study that analysed the planning and strategic documents. This was a result of the fact that processes different than suburbanisation shape the development of both communes.

Torunski Poviat, designated for the analysis, is located within the administrative borders of the Kujawsko-Pomorskie Voivodeship (administrative region of the 1st order in Poland). It consists of nine communes: Czernikowo, Lubicz, Łubianka, Łysomice, Obrowo, Wielka Nieszawka, Zławieś Wielka, and the city of Chełmża, and the rural commune of Chełmża. Toruński Poviat surrounds the centrally located city of Torun (administratively, the City of Torun Poviat) (Figure 3). As of 2019, 108,345 persons were living in Toruński Poviat, which covers an area of 1230 square kilometres. However, when considering the period 1999-2019, very dynamic population growth can be observed in the area. Back in 1999, the population of Toruński Poviat was only 80,302. In contrast, each subsequent year has seen a gradual increase. If 1999 were to be taken as $100 \%$, then, by 2019 , the rate of change in the population was already $134.9 \%$. This increase should be linked to suburbanisation processes, which are associated with the movement of the population, mainly from large cities (especially Torun in this case) to suburban communes. Communes in Toruński Poviat should be considered as such. The increase in population in the suburban communes is, therefore, linked to a simultaneous decline in the population of Torun. In 1999 , it was 211,955, while, by 2019, it had declined to 201,447, an almost $5 \%$ decrease in 20 years. Comparing the dynamic changes in the populations of both the suburban communes of Torunski Poviat and the city of Torun itself, to the changes in the population of Kujawsko-Pomorskie Voivodeship, it should be noted that, in the voivodeship, the population in the period 1999-2019 was fairly even and amounted to 2.07 million. This means that the largest population changes, regardless of the factors influencing them, take place in the city and its suburban zone.

This study focuses only on the suburban zone of Torun, eliminating the Bydgoszcz suburban zone from the analysis (even though it forms a bipolar system with Torun and its suburban zone). This represents a certain simplification, which was nevertheless necessary given the level of detail of the analysis. When discussing suburban zones, it is worth adding that, in the Polish context, these are the functional areas of the so-called "large" cities, which house more than 150,000 inhabitants and perform the functions of the voivodship capitals (cf. [76,77]). Both of these criteria are met by Torun and Bydgoszcz alike. Moreover, the suburban zones of both cities are fairly typical Polish suburban zones, which started to form after the systemic transformation, i.e., from the early 1990s. At present, the main direction of their development is determined by intensive socioeconomic processes connected with the process of suburbanisation [32]. 


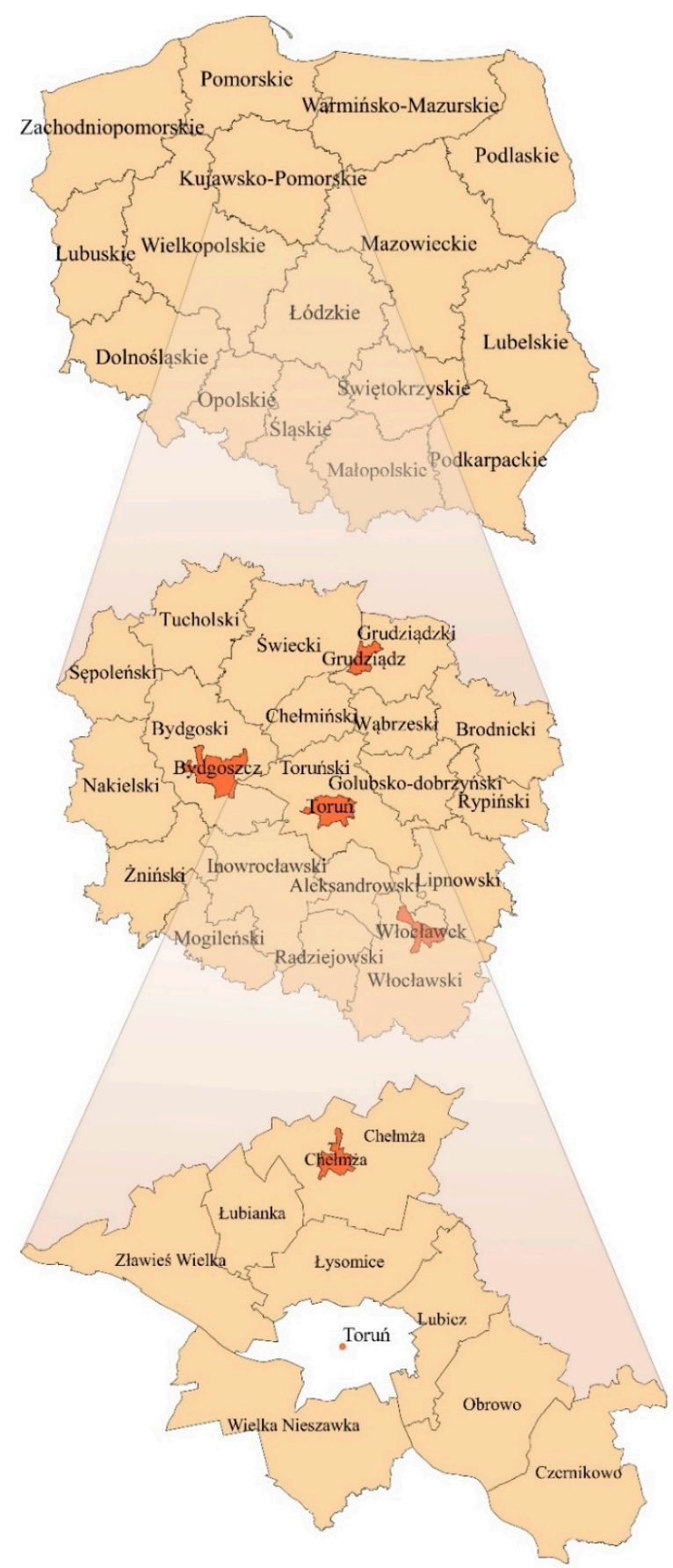

Figure 3. Location of Toruński Poviat in the context of Poland and Kujawsko-Pomorskie Voivodeship. Source: authors' own elaboration.

\section{Research Results}

4.1. Intensity of Construction Activity and Standard of Dwellings in Toruński Poviat in Comparison with Kujawsko-Pomorskie Voivodeship

The contemporary development of rural areas, caused by the suburbanisation process taking place therein, is characterised by strong dynamics of change. These transformations are noticeable mainly in terms of the construction activity, which is caused by the influx of populations, usually urban, into these areas. This is usually a population that is quite affluent and well-educated, justifying their move by a search for more favourable living conditions [28,78]. Therefore, in this study, the starting point in the Results Section was to trace the increase in the intensity of construction activity and find out how it is shaped 
in the communes of Torunski Poviat, and in the broader context of Kujawsko-Pomorskie Voivodeship, to show the specificity of these administrative units.

As J. Bański [79] points out, the specific landscape of suburban zones in Poland (but not only there) $[15,22-24,49]$ is shaped mainly by single-family housing. Therefore, the number of permits issued for the construction of a single-family house per 10,000 people in the population was tracked as the first indicator of the intensity of construction activity (Figure 4). In Poland, the ratio in 2002 was almost 10 permits per 10,000 inhabitants, but, by 2009 , it had risen to as many as 23 permits, and to 25 in 2019. Similar values were recorded in this respect for Kujawsko-Pomorskie Voivodeship: 9 (1999), 23 (2009), and 26 (2019) permits for the construction of a single-family house per 10,000 inhabitants. Against this background, the value of the indicator for Torunski Poviat was incomparably higher. There were 32 permits per 10,000 inhabitants in 2002, 72 in 2009, and 74 in 2019, about three times more than in Poland and Kujawsko-Pomorskie Voivodeship overall. If we consider the values of this indicator in Kujawsko-Pomorskie Voivodeship by poviats (Figure 1), we can see that, in general, its highest values (>72.0 permits per 10,000 inhabitants in 2019) were recorded in those territorial units that were suburban zones of the largest cities of the region, i.e., Bydgoszcz and Torun. These were Bydgoski Poviat and Toruński Poviat, respectively. In the other poviats, the number of single-family house-building permits was much lower. This spatial pattern remained unchanged despite the increased dynamics of the permits in the successive years under consideration. Therefore, it can be said with certainty that single-family housing is indeed a distinguishing feature of suburban zones. This is further confirmed by the fact that, when considering Torun with its suburban zones as an agglomeration, as many as $94.6 \%$ of building permits in this area were granted in Toruński Poviat.
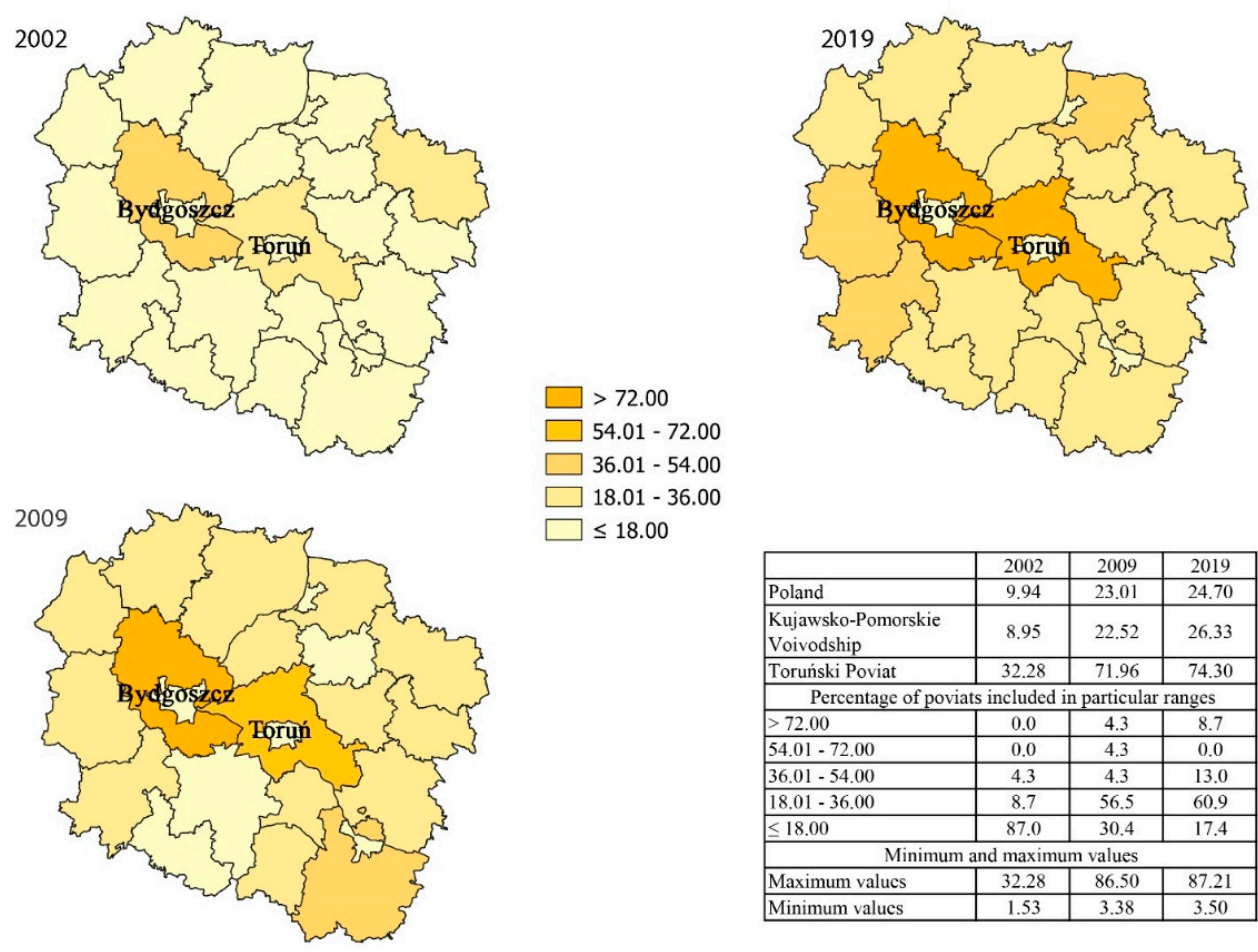

\begin{tabular}{|l|c|c|c|}
\hline & 2002 & 2009 & 2019 \\
\hline Poland & 9.94 & 23.01 & 24.70 \\
\hline $\begin{array}{l}\text { Kujawsko-Pomorskie } \\
\text { Voivodship }\end{array}$ & 8.95 & 22.52 & 26.33 \\
\hline Torunski Poviat & 32.28 & 71.96 & 74.30 \\
\hline \multicolumn{4}{|c|}{ Percentage of poviats included in particular ranges } \\
\hline$>72.00$ & 0.0 & 4.3 & 8.7 \\
\hline $54.01-72.00$ & 0.0 & 4.3 & 0.0 \\
\hline $36.01-54.00$ & 4.3 & 4.3 & 13.0 \\
\hline $18.01-36.00$ & 8.7 & 56.5 & 60.9 \\
\hline$\leq 18.00$ & 87.0 & 30.4 & 17.4 \\
\hline \multicolumn{4}{|c|}{ Minimum and maximum values } \\
\hline Maximum valucs & 32.28 & 86.50 & 87.21 \\
\hline Minimum valucs & 1.53 & 3.38 & 3.50 \\
\hline
\end{tabular}

Figure 4. Number of permits issued for the construction of a single-family house per 10,000 inhabitants in Kujawsko-Pomorskie Voivodeship. Source: authors' own elaboration, based on data from LDB CSO.

The intensity of the construction activity can also be analysed based on the number of dwellings completed per 1000 in the population (Figure 5). In Poland in general, this number has been increasing. Back in 2002, 2.5 dwellings per 1000 people were put into use, in 2009 it was already around 4, while, in 2019, it was as many as 5.4. This indicator was 
slightly lower in Kujawsko-Pomorskie Voivodeship than nationwide. In 2002, 2 dwellings per 1000 people were completed there, 3 dwellings in 2009, and almost 4 dwellings per 1000 people in 2019. Toruński Poviat certainly stands out against this background. In 2002, 3.3 dwellings per 1000 in the population were put into use there, but, in 2009, it was already 6.29, almost twice as many, and, in 2019, it was 6.94. Similarly, the high dynamics of the phenomenon is observed in Bydgoski Poviat, which allows for the conclusion that the suburban zones of the largest cities of the region have the highest number of dwellings completed.
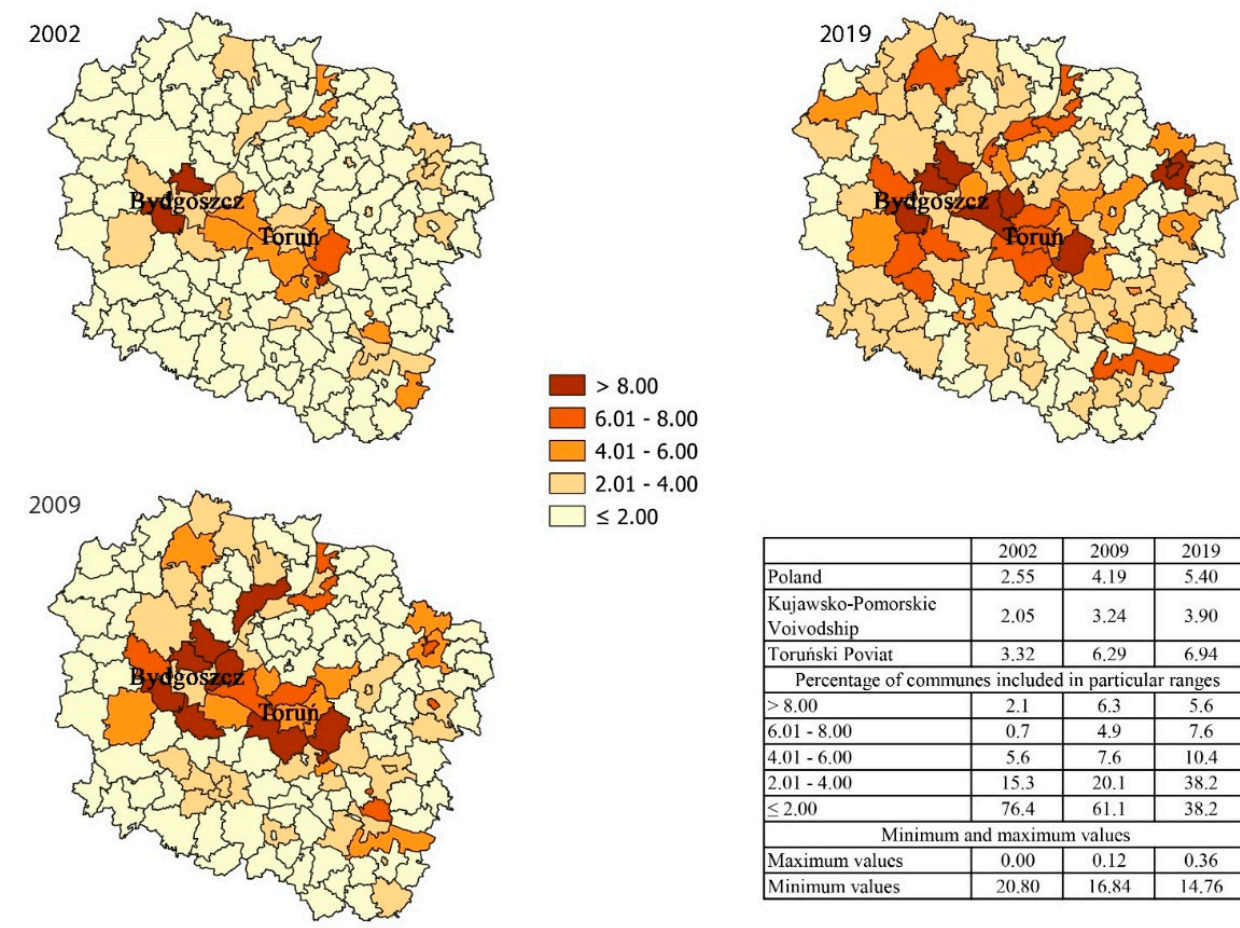

\begin{tabular}{|l|c|c|c|}
\hline & 2002 & 2009 & 2019 \\
\hline Poland & 2.55 & 4.19 & 5.40 \\
\hline $\begin{array}{l}\text { Kujawsko-Pomorskic } \\
\text { Voivodship }\end{array}$ & 2.05 & 3.24 & 3.90 \\
\hline Toruński Poviat & 3.32 & 6.29 & 6.94 \\
\hline \multicolumn{4}{|c|}{ Percentage of communes included in particular ranges } \\
\hline$>8.00$ & 2.1 & 6.3 & 5.6 \\
\hline $6.01-8.00$ & 0.7 & 4.9 & 7.6 \\
\hline $4.01-6.00$ & 5.6 & 7.6 & 10.4 \\
\hline $2.01-4.00$ & 15.3 & 20.1 & 38.2 \\
\hline$\leq 2.00$ & 76.4 & 61.1 & 38.2 \\
\hline \multicolumn{4}{|c|}{ Minimum and maximum values } \\
\hline Maximum valucs & 0.00 & 0.12 & 0.36 \\
\hline Minimum values & 20.80 & 16.84 & 14.76 \\
\hline \multicolumn{4}{|l}{}
\end{tabular}

Figure 5. Number of dwellings completed per 1000 inhabitants in Kujawsko-Pomorskie Voivodeship. Source: authors' own elaboration, based on data from LDB CSO.

The number of permits for the construction of single-family houses, and the number of dwellings put into use, indicate that the most dynamically developing area, in terms of the intensity of construction activity in Kujawsko-Pomorskie Voivodeship, is the BydgoszczTorun Metropolitan Area, including Toruński Poviat. While the big cities of the region recorded slightly higher-than-average values for the number of dwellings completed per 1000 in the population, and low values of the permits for the construction of a singlefamily house per 10,000 in the population (which results from the specific morphology and physiognomy of big cities in general), their suburban zones, including Torunski Poviat, showed a very high intensity of construction activity, expressed by the number of building permits and the number of dwellings completed.

The changes taking place in rural areas shown in this section on the basis of the selected indicators are determined by the progressing suburbanisation process in these areas. Construction activity is an element closely linked to population migration. Therefore, the significant influx of the population into suburban zones, including Toruński Poviat, drives the intensity of the construction activity.

\subsection{Planning of Construction Activity in the Suburban Zone of Torun in Light of Strategic and Planning Documents}

The dynamic, and often spontaneous, development of suburban zones in Poland makes it necessary to verify the development policies. To this end, this study reviewed planning and strategic documents, with a particular focus on the formation of construction activity, identified as one of the essential factors in the development of suburban 
areas $[61,80]$. We analysed key documents, both obligatory and nonobligatory, at the commune level: the Study of Conditions and Directions of Spatial Development, the Development Strategy, as well as Local Spatial Development Plans. Bearing in mind that these documents are developed in relation to higher-tier documents, reference was made to the National Spatial Development Concept, the Kujawsko-Pomorskie Voivodeship Development Strategy, and the Torunski Poviat Development Strategy.

The most general framework for Poland's spatial policy, including suburban zones, is provided by the National Spatial Development Concept 2030 (NSDC 2030) (Table 2). Importantly, this document considers suburban zones as part of a larger whole, i.e., the agglomeration. As the data presented in the NSDC 2030 indicate, $75-80 \%$ of the country's population lives in agglomerations, which supports the state's objective of concentrating settlements. Generally, the NSDC 2030 treats suburban zones as areas with good conditions for the spread of development processes; however, as its authors indicate, the management of these areas should respect the cultural heritage and rural landscape values. At the same time, the diversity of spatial layouts and the forms of rural settlements should be supported. Given the dependence of suburban zones on the city that produces them, the document envisages strengthening the links between them in the context of the better development of suburban zones, and creating urban regions consisting of both cities and their outer zones. The most significant indication resulting from the NSDC 2030 is the concern for sustainable development based on respecting spatial order. Given the spontaneity of urbanisation, and the growing spatial chaos in suburban zones diagnosed in the document, this assumption is most justified. The continued uncontrolled development, which is mainly due to the lack of proper control over construction activity, may primarily result in the degradation of the landscape and environment and, thus, also in a reduction in the recreational attractiveness of these areas. It is, therefore, proposed that restrictions be introduced on the disposal of areas not covered by the development plans. The NSDC 2030 makes another important assumption in the context of the construction activity in aiming to maintain the appropriate material and energy intensity of buildings, which should be applied during the entire construction cycle.

Table 2. Guidelines resulting from the National Spatial Development Concept 2030.

\begin{tabular}{|c|c|}
\hline & National Spatial Development Concept 2030 \\
\hline Main Assumptions & Guidelines Derived from the Strategy Document \\
\hline \multirow{3}{*}{ Shaping the settlement network } & strengthening the links between suburban zones and cities \\
\hline & $\begin{array}{c}\text { concentrating settlements (currently } 70-80 \% \text { of the country's population lives in agglomerations, i.e., cities } \\
\text { and their suburban zones) }\end{array}$ \\
\hline & $\begin{array}{l}\text { suburban areas are to be designated under the voivodeship development strategy and the Voivodeship } \\
\text { Spatial Development Plan as areas with good conditions for the spread of development processes }\end{array}$ \\
\hline \multirow{4}{*}{ Construction activity } & sustainable construction \\
\hline & construction aimed at reducing the material and energy intensity of buildings throughout the building cycle \\
\hline & $\begin{array}{l}\text { urbanisation of villages subject to legal and economic regulations supporting the achievement of spatial order, } \\
\text { preservation of cultural heritage and landscape values, and supporting the spatial diversity of rural } \\
\text { settlement systems and forms }\end{array}$ \\
\hline & taking measures to limit the disposal of land not covered by spatial development plans \\
\hline Technical infrastructure & developing water and sewage infrastructure \\
\hline
\end{tabular}
improving transport accessibility of subregional areas and local centres

Road infrastructure transport links to the network of major national centres will be given a higher priority than routes connecting subregions

Source: authors' own elaboration.

The elements of technical infrastructure, including road infrastructure, which is particularly important in relation to suburban zones, are indirectly connected to the shaping of the construction activity. In terms of the technical infrastructure in suburban areas, there is the need to improve the water and sewage infrastructure. This is due to the dis- 
persed development specific to these areas, which generates problems in providing the necessary facilities. Care should also be taken to develop the transport network, taking into account, in particular, the improvement in the access of the suburban zones to urban centres, which stems directly from the above-mentioned dependence of the zones on the cities that generate them.

Other aspects are raised in the Kujawsko-Pomorskie Voivodeship Development Strategy, which is the document that primarily defines the guidelines for the economic development of the area. Because of the fact that it is lower-tier to the above-discussed NSDC 2030, it refers directly to the communes of Torunski Poviat, which are key for the present study. Generally speaking, they belong to the Bydgoszcz-Torun agglomeration (or the Bydgoszcz-Torun Metropolitan Area), which includes Bydgoszcz and Torun and their suburban zones. The strategy indicates the internal developmental diversity of the suburban communes belonging to the agglomeration, but also their homogeneity in terms of morphology, physiognomy, or functions performed. It also outlines the division into suburban zones of Bydgoszcz and Torun, which may be questionable given the presence of metropolisation processes in the area, and the need to see them as a larger coherent whole.

However, what is particularly important, in view of the aim of this study, the KujawskoPomorskie Voivodeship Development Strategy (Table 3) emphasises that the pressure of construction in suburban communes results in spatial chaos. Therefore, the document accentuates the need for ordering the spatial-functional structure by making development more aesthetic. The issues strictly related to the construction activity are complemented by technical infrastructure, which, in the document, in the context of suburban zones, refers only to transport. It is, therefore, proposed to extend the transport network, especially from the big cities of the region to the suburban zones, stressing that its insufficient development could result in the transport exclusion of these areas.

Table 3. Guidelines resulting from the Kujawsko-Pomorskie Voivodeship Development Strategy until 2030.

\begin{tabular}{cr}
\hline \multicolumn{2}{c}{ Kujawsko-Pomorskie Voivodeship Development Strategy until 2030 } \\
\hline Main Assumptions & Guidelines Derived from the Strategy Document \\
\hline Shaping the settlement network & $\begin{array}{c}\text { deglomerating industry from city centres and zones of intensive } \\
\text { suburban development }\end{array}$ \\
\hline Construction activity & organising the functional and spatial structure of suburban zones \\
\hline Technical infrastructure & aesthetisising development \\
\hline Road infrastructure & reducing transport exclusion in peripheral areas \\
\hline
\end{tabular}

Source: authors' own elaboration.

Another document referred to in the study is the Torunski Poviat Development Strategy (Table 4), in which construction activity is considered with particular reference to environmental conditions. The document indicates that spatial planning and development should eliminate the impact of environmental hazards and seek an appropriate system for the planning and supervision of construction in reclaimed areas. In addition, the Development Strategy focuses on attempts to improve the energy grid and expand the sewage and gas networks, i.e., it seeks to develop investment areas with utilities, which is usually considered a weakness of suburban zones. The development of the technical infrastructure, which is emphasised in the strategy, is to take place in a coherent way through the cooperation of the communes of Torunski Poviat. In the context of transport, the construction of new roads is proposed as a way to improve the functioning of the road system, as well as to connect the external areas, i.e., the poviat's communes, with the city. 
Table 4. Guidelines resulting from the Toruński Poviat Development Strategy.

\begin{tabular}{|c|c|}
\hline & Toruński Poviat Development Strategy \\
\hline Main Assumptions & Guidelines Derived from the Strategy Document \\
\hline Shaping the settlement network & coherent development of suburban areas, cooperation of communes in the poviat \\
\hline \multirow{2}{*}{ Construction activity } & aiming at spatial planning and development that eliminates the impact of hazards \\
\hline & an appropriate system of planning and supervision of construction in reclaimed areas \\
\hline \multirow{4}{*}{ Technical infrastructure } & aiming to improve the accessibility of the energy network \\
\hline & developing sewage and gas networks \\
\hline & aiming at accessibility and development of investment areas with utilities \\
\hline & supporting communes in the construction of coherent technical infrastructure \\
\hline Road infrastructure & constructing new roads to improve the functioning of the road system \\
\hline
\end{tabular}

The analysis of the main problems in planning in the context of construction activity in the suburbs of Torun began with a review of the selected higher-tier documents. Being aware of the problems signalled there, and the solutions indicated, the authors examined the documents of a lower commune level in the analysed area.

As argued above, each of the communes selected for analysis has developed a set of strategic documents, both obligatory and optional (Table 5). Therefore, the presence of all possible documents in the communes under consideration should be seen as very positive. Each of these documents allows for the precise and long-term planning of the development of the suburban zone of Torun, including one of the most problematic elements, i.e., the construction activity. With regard to local spatial development plans, the authors established the percentage of the area of each commune they cover. Local plans define the commune's spatial policy most precisely, introducing recommendations and restrictions on land management. They are particularly important for suburban areas, where construction activity is characterised by extraordinary dynamics of change and often breeds spatial disorder. In this context, the values obtained here indicate significant disparities and, thus, differentiation in this respect, among the communes under consideration. In comparison to the communes included in the analysis, Lubicz commune stands out in particular, with $27.42 \%$ of its area covered by local plans. By comparison, in the next commune in terms of coverage by local plans, i.e., Wielka Nieszawka, this proportion was only $5.51 \%$ of the area and, similarly, in the commune of Zławieś Wielka, the proportion was $5.40 \%$. The communes of Łysomice (3.91\%), Łubianka (3.37\%), and Czernikowo (2.09\%) are also characterised by low coverage by local plans. Obrowo commune is at the end of the list, with only $0.62 \%$ of its area covered by local plans.

Table 5. Summary of strategic and planning documents for communes deemed the suburbs of Torun.

\begin{tabular}{|c|c|c|c|c|}
\hline Commune & $\begin{array}{l}\text { Study of Conditions and } \\
\text { Directions of Spatial } \\
\text { Development }\end{array}$ & Development Strategy & $\begin{array}{c}\text { Local Spatial } \\
\text { Development Plan }\end{array}$ & $\begin{array}{l}\% \text { of Area Covered by Local } \\
\text { Spatial Development Plans } \\
\text { (as of 2016) }\end{array}$ \\
\hline Czernikowo & + & + & + & $2.09 \%$ \\
\hline Lubicz & + & + & + & $27.42 \%$ \\
\hline Łubianka & + & + & + & $3.37 \%$ \\
\hline Łysomice & + & + & + & $3.91 \%$ \\
\hline Obrowo & + & + & + & $0.62 \%$ \\
\hline Wielka Nieszawka & + & + & + & $5.51 \%$ \\
\hline Zławieś Wielka & + & + & + & $5.40 \%$ \\
\hline
\end{tabular}


Having analysed the availability of the documents in each of the communes, which already provided a preliminary indication of how planned the formation of the suburban zone is, our next task was to carefully examine the content of these documents in the context of construction activity. It should be remembered that the Study of Conditions and Directions of Spatial Development, as well as the Development Strategy, consist of two parts. The Study comprises the conditions and directions of development, while the Development Strategy contains a diagnosis and a vision and mission for the development of the area. In both cases, the first part of the document reflects the current spatial development status of the commune, which forms the basis for determining the most appropriate use, while the second part refers to the recommended development directions.

In the context of the development of the construction activity in the suburban zone of Torun, all of the strategic and planning documents describe suburbanisation as a process that causes a dynamic constant increase in the share of the built-up areas, especially housing construction in the total commune area. The suburban character of the communes in relation to Torun is also indicated by the strong diffusion of housing, particularly single-family housing (all analysed communes except for Lubicz). Its scale makes Torun's suburban zones known as the city's "bedroom" areas. Additionally, the dynamics of housing development, mainly single-family housing, means that, in the absence of adequate control over spontaneous urbanisation, the historic settlement systems of villages will be destroyed, thus eroding their character and identity (Obrowo, Wielka Nieszawka). The communes' strategic documents indicate that residential development in the analysed suburbs is concentrated in the centres of the communes (Lubicz, Łysomice, Wielka Nieszawka) and along the main transport routes (Czernikowo, Łubianka, Obrowo, Zławieś Wielka), forming densely developed areas. Bearing in mind the relationship of suburban zones to the city in terms of daily commuting, such a pattern of development exacerbates congestion and consequently also increases traffic hazards. However, the concentration of housing in the centres of the communes, or along the main transport routes, should be perceived as an expected pattern of suburbanisation, while the concentration of residential development in the agricultural part of Obrowo commune is an undesired path of development. The same refers to the dispersed development away from the main transport routes $(\mathrm{Cz}$ ernikowo, Łysomice, and Obrowo). Its occurrence is an undesirable result of spontaneous urbanisation, causing difficulties in land management as well as in planning the technical infrastructure for such areas. In addition, there is a mixing of new development, usually residential, with earlier rural farmsteads. As these two functionally exclusive forms of development interweave, conflicts tend to arise, both social and in planning and space management. In addition, the expansion of housing development in the suburban communes of Torun is causing an irreversible shrinkage in recreational areas, whose shortage is already indicated in the communes under study (mainly in Lubicz). In addition to the elements mentioned, the documents indicate shortcomings in the use of local spatial development plans as instruments for the implementation of spatial policy (mainly Czernikowo). This implies that the development of these areas lacks precise direction (cf. Tables 6 and 7).

After analysing the fundamental problems associated with the current state of the development, the authors looked closely at elements indirectly related to construction activity. In the context of technical infrastructure, the focus was on determining the levels of development of the water supply, sewage, and gas networks. The analysis of the strategic and planning documents shows that all communes are considered to be wellshaped in terms of water supply, but only two communes (Wielka Nieszawka and Zławieś Wielka) in terms of the sewage network. Moreover, some communes (Czernikowo, Lubicz, Łubianka, and Łysomice) have problems with access to the gas network. The difficulty in providing adequate technical infrastructure is caused by the scattered development, imposing, among other things, the construction of domestic sewage treatment plants. As far as the transport network of the communes is concerned, it is well-developed, but the poor technical condition of the roads, mainly the commune roads, is often pointed out (cf. Tables 6 and 7). 
Table 6. Issues arising from strategic and planning documents-current state.

\begin{tabular}{|c|c|}
\hline & Construction Activity at Commune Level, Status Diagnosis \\
\hline Main Assumptions & Guidelines Derived from the Strategy Document \\
\hline \multirow{5}{*}{ Construction activity } & $\begin{array}{c}\text { dynamic, constant increase in the share of built-up areas, especially residential, including a strong } \\
\text { diffusion of single-family housing }\end{array}$ \\
\hline & $\begin{array}{l}\text { concentration of residential development in the centres of communes and along main transport } \\
\text { routes, occurrence of dispersed development far from main transport routes }\end{array}$ \\
\hline & $\begin{array}{l}\text { mixed new housing and existing farmsteads (social conflicts, difficulties in space management), } \\
\text { destruction of historical spatial arrangements of villages and lack of reference to local architectural } \\
\text { elements in new buildings (obliteration of local character and identity) }\end{array}$ \\
\hline & $\begin{array}{c}\text { appropriation of recreational land for development (significant lack of recreational land in } \\
\text { suburban zones) }\end{array}$ \\
\hline & $\begin{array}{l}\text { shortcomings in the use of local spatial development plans as instruments for the implementation of } \\
\text { spatial policy. }\end{array}$ \\
\hline Technical infrastructure & $\begin{array}{l}\text { generally well-developed technical infrastructure (water supply, sewage system, gas supply); } \\
\text { difficulties in providing adequate technical infrastructure in areas with dispersed development }\end{array}$ \\
\hline \multirow[t]{3}{*}{ Road infrastructure } & $\begin{array}{l}\text { a fairly well-developed transport network in the communes; however, attention is often drawn to the } \\
\text { poor technical condition of roads, especially commune roads; high intensity of road traffic connected } \\
\text { mainly with commuting to Torun (traffic jams, hazards) }\end{array}$ \\
\hline & Source: authors' own elaboration. \\
\hline & $\begin{array}{l}\text { As shown above, on the basis of the strategic documents, the suburban communes } \\
\text { of Torun exhibit land development typical for suburban zones, which often takes place } \\
\text { in an unplanned manner. As a result, attempts are being made to restore the spatial } \\
\text { balance in these areas by determining their most appropriate development in the strategic } \\
\text { and planning documents. The development directions of the communes were analysed } \\
\text { on the basis of their Studies of Conditions and Directions of Spatial Development and } \\
\text { Development Strategies, as well as the guidelines for the preparation of the Local Spatial } \\
\text { Development Plans. }\end{array}$ \\
\hline
\end{tabular}

Table 7. Issues arising from strategic and planning documents—current state for all communes.

\begin{tabular}{|c|c|c|c|c|c|c|c|}
\hline Specification & Czernikowo & Lubicz & Łubianka & Łysomice & Obrowo & $\begin{array}{c}\text { Wielka } \\
\text { Nieszawka }\end{array}$ & $\begin{array}{l}\text { Zławieś } \\
\text { Wielka }\end{array}$ \\
\hline $\begin{array}{l}\text { residential development concentrated along } \\
\text { the main transport routes }\end{array}$ & + & & + & & + & & + \\
\hline $\begin{array}{l}\text { residential development concentrated in the } \\
\text { centres of the commune }\end{array}$ & & + & & + & & + & \\
\hline $\begin{array}{l}\text { residential development concentrated in the } \\
\text { agricultural part of the commune }\end{array}$ & & & & & + & & \\
\hline $\begin{array}{l}\text { dominance of residential function, strong } \\
\text { spread of single-family housing }\end{array}$ & + & & + & + & + & + & + \\
\hline $\begin{array}{c}\text { most of new housing in an architectonic } \\
\text { style not corresponding to the existing } \\
\text { dwellings, the historic settlement systems of } \\
\text { villages destroyed }\end{array}$ & & & & & + & + & \\
\hline $\begin{array}{c}\text { land reserved for housing development } \\
\text { or services }\end{array}$ & + & & & & & & \\
\hline $\begin{array}{l}\text { tendency for dispersed housing } \\
\text { development }\end{array}$ & + & & & + & + & & \\
\hline $\begin{array}{l}\text { shortcomings in the use of local spatial } \\
\text { development plans as instruments for the } \\
\text { implementation of spatial policy }\end{array}$ & + & & & & & & \\
\hline well-developed water supply & + & + & + & & + & + & + \\
\hline problems with access to the sewage network & + & + & + & + & + & & \\
\hline problems with access to the gas network & + & + & + & + & & & \\
\hline $\begin{array}{c}\text { good location in terms of communication, } \\
\text { well-developed transport network }\end{array}$ & + & + & + & & + & + & + \\
\hline poor technical condition of roads & + & + & + & + & + & & + \\
\hline shrinkage of recreational areas & & + & & & & & \\
\hline
\end{tabular}


To begin with, it should be noted that the process of suburbanisation, although unfavourable from the point of view of spatial policy, gives communes, which have so far been in the shadow of the local centre, a chance for development. The analysed documents indicate an aspiration to maintain the trend of population migration to nonurban areas; at the same time, they strive to minimise the negative consequences this entails as much as possible. Communes are focused on offering better and better housing conditions, undertaking both the intensive development of residential zones and raising the standard of these dwellings, while, at the same time, calling for the rational use of space, with respect for spatial order. Hence, most communes (except for Czernikowo and Obrowo) try to rationally use space while preserving natural and cultural values. A specific problem characteristic of suburban zones, which is also faced by the analysed communes (Czernikowo, Łysomice, and Wielka Nieszawka), is dispersed development. This is largely the result of previous construction permits granted in an unplanned or rather arbitrary manner, without anticipating the consequences that this would entail. As such, the documents take measures to limit further dispersal by favouring additions to existing development, or by limiting the location of new farmstead development. Moreover, attention is also paid to harmoniously fitting new development into the existing surroundings of the commune, and adapting its character, height, or roof shape to the existing buildings, thus limiting the marginalisation of the cultural-historical physiognomy (all communes except for Czernikowo and Obrowo). In addition, the documents postulate the better quality of public space (Obrowo), and the separation of the service centre of the commune (Czernikowo, Lubicz, and Zławieś Wielka), the lack of which is also a distinctive feature of the suburban zones. Only one commune (Łubianka) mentioned that there is a need to cover a larger area by local spatial development plans. Two communes, i.e., Czernikowo and Łubinka, declared the development of infrastructure for newly built houses, services, and recreational purposes. One commune (Lubicz) notices the need to keep the distance from the forest line and to provide acoustic comfort for inhabitants. Unfortunately, apart from this, there are no concrete indications in the documents on how to meet the rising demand for a more comprehensive offer of services in the communes. Moreover, some irrational postulates were also diagnosed, such as rational spatial planning only in the neighbourhood of the commune centre (Czernikowo), acceptance for dispersed housing (Czernikowo and Obrowo), and further intensive development of space for the residential function (Łubianka, Obrowo, and Zławieś Wielka) (Tables 8 and 9).

Table 8. Topics arising from strategic and planning documents-directions of development.

\begin{tabular}{|c|c|}
\hline & Construction Activity at Commune Level, Development Directions \\
\hline Main Assumptions & Guidelines Derived from the Strategy Document \\
\hline \multirow{6}{*}{ Construction activity } & $\begin{array}{l}\text { intensive development of residential areas and raising the standard of these dwellings, while calling for rational } \\
\text { use of space, with respect for spatial order }\end{array}$ \\
\hline & $\begin{array}{c}\text { preventing the further dispersion of development by favouring the completion of existing buildings, or restricting } \\
\text { the location of new farm buildings }\end{array}$ \\
\hline & $\begin{array}{l}\text { fitting the new development into the existing surroundings of the commune in a harmonious way, adapting its } \\
\text { character, height, and roof shape to the existing buildings, thus limiting the marginalisation of the } \\
\text { cultural-historical physiognomy }\end{array}$ \\
\hline & $\begin{array}{l}\text { identifying a central service centre for the commune (no specific indications to address the lack of adequate } \\
\text { service facilities in suburban zones) to improve the quality of life of inhabitants }\end{array}$ \\
\hline & $\begin{array}{c}\text { developing areas for recreational and leisure functions (the problem is, however, the shrinkage of area that can be } \\
\text { designated for these purposes) }\end{array}$ \\
\hline & extending the scope of local spatial development plans in the context of directing construction activity \\
\hline Technical infrastructure & increasing the coverage and reconstructing the water and sewage network serving existing and planned plots \\
\hline Road infrastructure & modernising road infrastructure \\
\hline
\end{tabular}


Table 9. Topics arising from strategic and planning documents-directions of development for all communes.

\begin{tabular}{|c|c|c|c|c|c|c|c|}
\hline Specification & Czernikowo & Lubicz & Łubianka & Łysomice & Obrowo & $\begin{array}{c}\text { Wielka } \\
\text { Nieszawka }\end{array}$ & $\begin{array}{l}\text { Zławieś } \\
\text { Wielka }\end{array}$ \\
\hline $\begin{array}{l}\text { rational use of space with respect } \\
\text { for spatial order }\end{array}$ & & + & + & + & & + & + \\
\hline $\begin{array}{l}\text { shaping spatial order by } \\
\text { preventing dispersed housing }\end{array}$ & + & & & + & & + & \\
\hline $\begin{array}{l}\text { shaping spatial order by } \\
\text { providing services }\end{array}$ & + & + & & & & & + \\
\hline $\begin{array}{l}\text { harmony of new buildings with } \\
\text { the existing surroundings }\end{array}$ & + & + & + & + & + & + & \\
\hline $\begin{array}{l}\text { renewal and management of } \\
\text { public space }\end{array}$ & & & & & + & & \\
\hline $\begin{array}{l}\text { a need to develop local spatial } \\
\text { development plans }\end{array}$ & & & + & & & & \\
\hline $\begin{array}{l}\text { rational spatial planning only in } \\
\text { the neighbourhood of the } \\
\text { commune centre }\end{array}$ & + & & & & & & \\
\hline acceptance for dispersed housing & + & & & & + & & \\
\hline $\begin{array}{l}\text { further intensive development of } \\
\text { space for residential function }\end{array}$ & & & + & & + & & + \\
\hline $\begin{array}{l}\text { development of infrastructure for } \\
\text { newly built houses and services }\end{array}$ & + & & + & & & & \\
\hline $\begin{array}{l}\text { infrastructure for } \\
\text { recreational purposes }\end{array}$ & + & & + & & & & \\
\hline $\begin{array}{l}\text { higher coverage or reconstruction } \\
\text { of the water network }\end{array}$ & + & + & + & + & + & + & + \\
\hline $\begin{array}{l}\text { higher coverage or reconstruction } \\
\text { of the sewage network }\end{array}$ & + & + & + & + & + & + & + \\
\hline $\begin{array}{l}\text { modernization of roads, building } \\
\text { new roads }\end{array}$ & + & + & + & + & + & + & + \\
\hline
\end{tabular}

Source: authors' own elaboration.

Considering the elements indirectly related to construction activity, i.e., technical infrastructure, there are plans to increase the coverage or reconstruct the water and sewage networks serving the existing plots, as well as those planned for investments in all communes. Elsewhere, the road infrastructure should be modernised by improving the technical condition of the roads, and new sections of commune roads should be built (Tables 8 and 9).

Higher-tier documents provide a list of the main directions of spatial development in the area and set top-down principles, which should also be followed in commune-level documents. As a result, top-down directives are understandably reflected and made more specific only in local planning and strategic documents. In the case of shaping construction activity in suburban zones, higher-tier documents impose only general principles of spatial development, which are followed in the analysed commune documents. The latter additionally propose other solutions, adjusted to the individual needs of the commune, as shown in the case of the suburbs of Torun considered. These measures, in the context of suburban zones and construction activity, certainly have a very important function. They make it possible to respond to the expectations of both current and incoming residents, but, above all, they aim at the rational management of space as a resource.

\section{Conclusions}

\subsection{Conclusions in Relation to Obtained Research Results}

In the present section, we identify the areas potentially at risk for inappropriate land use direction, and those with a direction potentially not giving rise to such concerns. Table 10 presents the indicators of construction activity, as well as information on the share of each commune's area covered by local spatial development plans (LSDP), and data on 
the scale of the problems diagnosed in the strategic and planning documents. This allowed us to identify scenarios indicating the potential direction of the changes taking place.

Table 10. Suburban development scenario in the context of construction activity and strategic and planning documents.

\begin{tabular}{|c|c|c|c|c|c|}
\hline & Activity Level & Growth Rate & $\begin{array}{c}\text { Local Spatial } \\
\text { Development Plan } \\
\text { Coverage }\end{array}$ & $\begin{array}{l}\text { Number of } \\
\text { Problems } \\
\text { Diagnosed }\end{array}$ & $\begin{array}{l}\text { Suburban Development Scenario in the } \\
\text { Context of Construction Activity and } \\
\text { Strategic and Planning Documents }\end{array}$ \\
\hline Czernikowo & low & high & low & high & very risky \\
\hline Lubicz & low & low & high & low & very favourable \\
\hline Łubianka & average & high & low & low & risky \\
\hline Łysomice & average & average & average & average & moderate \\
\hline Obrowo & high & average & low & high & veryrisky \\
\hline Wielka Nieszawka & low & low & average & low & favourable \\
\hline Zławieś Wielka & average & low & average & average & moderate \\
\hline
\end{tabular}

Source: authors' own elaboration.

Among the analysed communes, three units were designated for which a risky development scenario should be considered. In the communes of Obrowo and Czernikowo, the scenario was even described as very risky. In the first of these units, we are dealing with an accumulation of factors potentially threatening the sustainable development of the suburban zone. These are: (a) A very high level of construction activity, as measured by the number of dwellings completed per 10,000 inhabitants (140 in 2019); (b) An average rate of growth of this parameter (the process is ongoing); (c) An especially low coverage of land with LSDP $(0.62 \%)$; and (d) Numerous problems diagnosed in the strategic and planning documents. The neighbouring commune of Czernikowo is characterised by similar features. In this case, only the level of construction activity measured by the number of dwellings completed is lower (58 per 10,000 inhabitants), but its growth rate in the last two decades (4756.2\% in relation to 2002) is significant. This shows that we are dealing with a very similar scenario of changes, especially that, in both of the mentioned units, a particularly large number of development problems have been identified, and changes in the spaces are based on planning concepts only to a small extent (low degree of land coverage by LSDP). The commune of Łubianka is also included in the group of units where a risky development scenario has been identified. Although, in this case, there is an average number of dwellings per 10,000 inhabitants (8.9), it is accompanied by very high dynamics in changes of this indicator $(1242.2 \%)$, low LSDP coverage (3.37\%), with a currently low number of diagnosed problems. Thus, Łubianka should also be included in the group of communes in which the established scenario may be a warning against the risk of entering into an undesirable development trajectory.

The other communes are characterised by much more favourable conditions. Above all, the dynamics in terms of the construction activity reaches a low-to-medium level here, which means that the process of change is not so intense as to be difficult to control. Thus, the documents confirm that the scale of the diagnosed problems is not particularly large. In addition, the average land coverage by LSDP is favourable.

Of the communes belonging to Torun's suburban zone, two have a direction of development that is considered moderate (Łysomice and Zławieś Wielka), one favourable (Wielka Nieszawka), and one very favourable (Lubicz). The last of the mentioned units stands out in particular as it is characterised by a very high share of LSDP coverage (27.42\%) in comparison with the other communes. This is also linked to the very low number of problems diagnosed in the strategic and planning documents. The rate of residential suburbanisation is not as high in Lubicz commune as in the neighbouring Obrowo commune. This is due to the fact that the highest dynamics of housing development take place on land located quite close to the main transport axis (road towards Warsaw) and, in Lubicz commune, such land is no longer available. It is either already in use or is designated for other purposes (transport areas-motorway, and investment areas related to industry, logistics services, etc.). 


\subsection{Final Reflections in Terms of Literature}

A key asset that a suburban area provides for its residents is space. However, it is a rare and limited good. Thus, suburbanisation associated with intensive population influx leads to a disjunction between individual and social rationality in spatial management [37]. From an individual point of view, the opportunity to live in a suburban area provides a number of benefits: (a) Living in a friendly environment and peaceful surroundings; (b) Improved housing conditions; (c) Opportunities for outdoor recreation; (d) Greater privacy and freedom; (e) A lower tax burden; and (f) Lower costs compared to cities for acquiring a plot of land, building a house, or buying a flat, etc. However, it is crucial to pay attention to the society's point of view, which emphasises that suburbanisation leads to: (a) Irrational use of land; (b) Depletion of agricultural land; (c) Increased costs of building infrastructure in dispersed areas; and (d) Generation of heavy traffic, etc. [32].

According to a report by the European Environmental Agency [81], the whole of Europe, although in a better situation than the USA in this respect [82], appears to be a continent on which the development of functional urban regions takes place mainly through urban sprawl, i.e., suburbanisation, whose main characteristics are a relatively low population density, a lack of continuity, and dispersed urban development. Between 1950 and 1990 alone, so-called "urban" areas increased their area by $78 \%$, although the urban population increased by only 33\%. Moreover, between 1990 and 2000, the area of urbantype development, typically comprising housing and business with associated transport infrastructure, increased by 800,000 ha $(5.4 \%)$, and irretrievably consumed $0.25 \%$ of the total area of agricultural, forest, and natural land. If the pace of these changes continues, a range of new environmental and climate problems will emerge over the next 50-100 years, in addition to the huge concentration of populations in functional urban regions [83].

One of the main problems highlighted in the EEA reports is the huge consumption of space in Europe associated with suburbanisation. Only from the middle of the 20th century to the beginning of the 21st century has the space per person doubled in European areas with urban development [81]. Moreover, in the mid-2000s, it was signalled, for the first time, that tendencies towards the irrational disposal of space around cities also appears in CEE countries. Already then, some of them were included in the group of European countries with the most irrational spatial management, for their territory had seen a $20 \%$ increase in the area of urban-type development, while only a $6 \%$ increase in the respective population [81]. Income growth was identified among the main factors influencing the intensification of urban sprawl in Central and Eastern Europe. This translates into changes in the social structure and a general increase in liberalisation, leading to the individualisation of behaviour. One manifestation of this individualisation is the dream of owning one's own single-family home. This dream is further strengthened by having a flat in an old block of flats, an unattractive city centre, and the proliferation of the private car.

The irrationality of the Polish suburbanisation process, and its spontaneity and chaotic nature, are indicated in a number of Polish studies and reports [84-86]. Among the main causes of suburbanisation in the form of urban sprawl are the faulty spatial policies of communes and the faulty functional structures of local plans, which cause communes to allocate too large areas for housing development, usually exceeding their needs and economic potential. According to estimates of demographic absorption, about 62 million people can settle in the areas covered by local plans, and 167-229 million in the areas covered by the studies of conditions and directions of spatial development, i.e., several times more than the current population of the country. As a result, at the current implementation rate of construction projects, mainly involving single-family homes, this yields construction reserves of 150-210 years [85]. The rather liberal approach of communes to the issue of changing land use from agricultural to other purposes, and land allocation for construction purposes, is related to the fact that, in it, they see an opportunity to increase budget revenues. Meanwhile, the influx of the population into suburban communes does not always translate into tangible revenue for the commune's budget [87]. What is more, ineffective spatial management brings with it the danger of investment risks, inflated 
costs of land acquisition for public investment, and limited inflow of economic investment. Dispersed and chaotic development results in the fragmentation of agricultural areas and areas of natural value (or even protected areas), the loss of the zoning fee, the costs of the destruction of development and the accompanying infrastructure in areas unsuitable for such purposes, and the high costs of construction and the maintenance of technical infrastructure [66]. The irrational management of space is also influenced by the fragmentation of land plots and farms, and the lack of cooperation between the communes of the suburban zone in terms of implementing a coherent vision for shaping further the social and economic development of these areas. As a result, the dispersion of development contributes to: (a) Consolidation of the spatial chaos, manifesting itself in the disturbance of the compositional and functional arrangement of the original settlement structures; (b) Co-existence of residential development and agricultural land; and (c) Loss of aesthetic and landscape values of the surroundings, ultimately leading to a decrease in the economic value of the land and a deterioration in the quality of life of the inhabitants.

Adverse trends in spatial management should also be viewed from the perspective of demographic projections, which predict that suburbanisation will be the main process affecting the transformation of space and society in Poland [60]. Given the general increase in the affluence and mobility of the population, improvements in the means of transport, increasing opportunities for remote work, and the resulting socially perpetuated notion of an idyllic rural life as a remedy for the problems of an urbanising society, this seems far from unlikely. Thus, the appropriate management of space to ensure the economic competitiveness of suburban areas, and the quality of life of their inhabitants, should be a priority for the local authorities.

Author Contributions: Conceptualization, D.W., J.B. and E.G.-K.; methodology, D.W., J.B. and E.G.-K.; software, D.W., J.B. and E.G.-K.; validation, D.W., J.B. and E.G.-K.; formal analysis, D.W., J.B. and E.G.-K.; investigation, D.W., J.B. and E.G.-K.; resources, D.W., J.B. and E.G.-K.; data curation, D.W., J.B. and E.G.-K.; writing—original draft preparation, D.W., J.B. and E.G.-K.; writing-review and editing, D.W., J.B. and E.G.-K.; visualization, D.W., J.B. and E.G.-K.; supervision, D.W., J.B. and E.G.-K.; project administration, D.W.; funding acquisition, E.G.-K. All authors have read and agreed to the published version of the manuscript.

Funding: This research received the external funding from Nicolaus Copernicus University in Torun (Poland).

Conflicts of Interest: The authors declare no conflict of interest.

\section{Notes}

Commune-administrative unit of the 3rd order in Poland.

Voivodeship_administrative unit of the 1st order in Poland.

Poviat-administrative unit of the 2rd order in Poland.

Commune-administrative unit of the 3rd order in Poland.

\section{References}

1. Tisdale, H. The process of urbanization. Soc. Forces 1942, 20, 311-316. [CrossRef]

2. Smailes, A.E. The Definition and Measurement of Urbanization. In Essays on World Urbanization; Jones, R., Ed.; George Philip and Son Ltd.: London, UK, 1975; pp. 1-18.

3. Pahl, R.E. The rural-urban continuum. Sociol. Rural. 1966, 6, 299-327. [CrossRef]

4. Tilly, C. The state of urbanization. Comp. Stud. Soc. Hist. 1967, 10, 100-113. [CrossRef]

5. Hiday, V.A. Migration, Urbanization, and Fertility in the Philippines. Int. Migr. Rev. 1978, 12, 370-385. [CrossRef]

6. Dutt, A.K.; Monroe, C.B.; Vakamudi, R. Rural-Urban Correlates for Indian Urbanization. Geogr. Rev. 1986, 76, 173-183. [CrossRef]

7. Lowry, I.S. World Urbanization in Perspective. Popul. Dev. Rev. 1990, 16, 148-176. [CrossRef]

8. Potter, R.B.; Unwin, T. Urban-rural interaction: Physical form and political process in the Third World. Cities 1995, 12, 67-73. [CrossRef]

9. Beggs, J.J.; Haines, A.V.; Hurlburt, J.S. Revisiting the rural-urban contrast: Personal networks in nonmetropolitan and metropolitan settings. Rural. Sociol. 1996, 61, 306-325. [CrossRef] 
10. Long, H.; Heilig, G.K.; Li, X.; Zhang, M. Socio-economic development and land-use change: Analysis of rural housing land transition in the Transect of the Yangtse River, China. Land Use Policy 2007, 24, 141-153. [CrossRef]

11. van den Berg, L.; Drewett, R.; Klaassen, L.H.; Rossi, A.; Vijverberg, C.H.T. Urban Europe: A Study of Growth and Decline; Pergamon Press: Oxford, UK; New York, NY, USA; Toronto, ON, Canada; Sydney, Australia; Paris, France; Frankfurt, Germany, 1982.

12. Dymitrow, M.; Stenseke, M. Rural-urban blurring and the subjectivity within. Rural. Landsc. Soc. Environ. Hist. 2016, 3, 4. [CrossRef]

13. Dymitrow, M.; Biegańska, J.; Grzelak-Kostulska, E. Deprivation and the rural-urban trap. Tijdschr. Voor. Econ. En. Soc. Geogr. 2018, 109, 87-108. [CrossRef]

14. Pile, S. What is a city? In City Worlds; Massey, D., Allen, J., Pile, S., Eds.; Routledge: New York, NY, USA, 1999 ; pp. 3-53.

15. Woods, M. Rural; Routledge: New York, NY, USA, 2010.

16. Krzysztofik, R.; Dymitrow, M.; Biegańska, J.; Senetra, A.; Gavriilidou, E.; Nadolu, B.; Kantor-Pietraga, I.; Grzelak-Kostulska, E.; Oureilidou, E.; Luches, D.; et al. Landscapes with defferent logics: A physicalist approach to semantic conflicts in spatial planning. Quaest. Geogr. 2010, 36, 29-45. [CrossRef]

17. Krzysztofik, R.; Dymitrow, M.; Grzelak-Kostulska, E.; Biegańska, J. Poverty and social exclusion: An alternative spatial explanation. Bull. Geography. Socio Econ. Ser. 2017, 35, 45-64. [CrossRef]

18. Szymańska, D.; Matczak, A. Urbanization in Poland: Tendencies and Transformation. Eur. Urban Reg. Balances 2002, 9, 39-46. [CrossRef]

19. Kaplan, D.H.; Wheeler, J.O.; Holloway, S.R. Urban Geography; Wiley\&Sons Press: Hoboken, NJ, USA, 2004.

20. Downs, A. The Vision for Metropolitan America; Brookings: Washington, DC, USA, 1994.

21. Ruoppila, S.; Kährik, A. Socio-economic residential differentiation in postsocialist Tallinn. J. Hous. Built Environ. 2003, 18, 49-73. [CrossRef]

22. Ouředniček, M. Differential suburban development in the prague urban region. Geogr. Ann. Ser. B Hum. Geogr. 2007, 89, 111-126. [CrossRef]

23. Krišjāne, Z.; Bērziñš, M. Post-socialist Urban Trends: New Patterns and Motivations for Migration in the Suburban Areas of Rīga, Latvia. Urban Stud. 2012, 49, 289-306. [CrossRef]

24. Tóth, V. Urban development of Bratislava: Suburbanization in years 1995-2009. J. Geogr. 2012, 7, 115-126.

25. Lisowski, A. Janusowe oblicze suburbanizacji. (Janus' face of suburbanization). In Wspótczesne Procesy Urbanizacji i ich Skutki (s. 91-100); Jażdzewska, W.I., Ed.; Wydawnictwo Uniwersytetu Łódzkiego: Łódź, Poland, 2005.

26. Lisowski, A.; Grochowski, M. Procesy suburbanizacji. Uwarunkowania, formy i konsekwencje. (Suburbanization processes. Conditions, forms and consequences); In Ekspertyzy do Koncepcji Przestrzennego Zagospodarowania Kraju 2008-2033; Saganowski, W.K., Zagrzejewska-Fiedorowicz, M., Żuber, P., Eds.; Ministerstwo Rozwoju Regionalnego: Warszawa, Poland, 2009; Volume 1, pp. 217-280.

27. Groeger, L. Programy wspierania budownictwa mieszkaniowego w Polsce i ich wpływ na rynek nieruchomości mieszkaniowych. (Residential construction support programs in Poland and their impact on the residential real estate market). Space Soc. Econ. 2016, 18, 131-146. [CrossRef]

28. Biegańska, J.; Środa-Murawska, S.; Kruzmetra, Z.; Swiaczny, F. Peri-urban development as significant rural development trend. Quaest. Geogr. 2018, 37, 125-140. [CrossRef]

29. Fielding, A.J. Migration and urbanization in Western Europe since 1950. Geogr. J. 1989, 155, 60-69. [CrossRef]

30. Kirby, A.; Modarres, A. The Suburban Question: An introduction. Cities 2010, 27, 65-67. [CrossRef]

31. Biegańska, J. Dysfunctionality vs. urban-rural solutions: Can it work? In Proceedings of the Keynote at: Mistra Urban Futures 2018, Wicked Problems or Wicked Solutions? Sustainability-Differently, Gothenburg, Sweden, 18 September 2018.

32. Biegańska, J. Społeczno-Geograficzny Wymiar Przemian Stref Podmiejskich w Polsce; (The socio-geographical dimension of the transformation of suburban zones in Poland); Uniwersytet Mikołaja Kopernika: Torun, Poland, 2019.

33. Antrop, M. Changing patterns in the urbanized countryside of Western Europe. Landsc. Ecol. 2000, 15, 257-270. [CrossRef]

34. Caruso, G. Periurbanisation, the Situation in Europe: A Bibliographical Note and Survey of Studies in the Netherlands, Belgium, Great Britain, Germany, Italy and the Nordic Countries. Final Report. 2001. Available online: http://publications.uni.lu/ bitstream/10993/10153/1/Caruso_PeriUrbanEuropeDATAR.pdf (accessed on 31 October 2021).

35. Brown, D.L.; Schafft, K.A. Population deconcentration in Hungary during the post-socialist transformation. J. Rural. Stud. 2002, 18, 233-244. [CrossRef]

36. Fuguitt, G.V. Some demographic aspects of rurality. Res. Soc. Stratif. Mobil. 2005, 22, 73-90. [CrossRef]

37. Lewyn, M. Government Intervention and Suburban Sprawl. The Case for Market Urbanism; Palgrave Macmillan: London, UK, 2017. [CrossRef]

38. Coombes, M.; Longga, R.D.; Raybould, S. Counterurbanisation in Britain and Italy: A comparative critique of the concept, causation and evidence. Prog. Plan. 1989, 32, 1-70. [CrossRef]

39. Champion, A.; Vandermotten, C. Migration, Counterurbanization and Regional Restructuring in Europe. In People, Jobs and Mobility in the New Europe; Blotevogel, H.H., Fielding, A.J., Eds.; Wiley: Chichester, UK, 1997; pp. 69-90.

40. Hirt, S. Suburbanizing Sofia: Characteristics of post-socialist peri-urban change. Urban Geogr. 2007, 28, 755-780. [CrossRef]

41. Węcławowicz, G. Social polarisation in postsocialist cities: Budapest, Prague and Warsaw. In Social Change and Urban Restructuring in Central Europe; Enyedi, W.G., Ed.; Akadémiai Kiadó: Budapest, Hungary, 1998; pp. 55-66. 
42. Sýkora, L. Changes in the internal structure of post-communist Prague. GeoJournal 1999, 49, 79-89. [CrossRef]

43. Ouředniček, M.; Temelová, J. Twenty years after socialism: The transformation of Prague's inner structure. Studia Univ. Babeş Bolyai. Sociol. 2009, 54, 9-30.

44. Sýkora, L.; Bouzarovski, S. Multiple Transformations Conceptualising the Post-communist Urban Transition. Urban Stud. 2012, 49, 43-60. [CrossRef]

45. Dumitrache, L.; Zamfir, D.; Nae, M.; Simion, G.; Stoica, I.-V. The Urban Nexus: Contradictions and Dilemmas of (Post) Communist (Sub) Urbanization in Romania. Hum. Geogr. 2016, 10, 39-58. [CrossRef]

46. Novotný, L. Urban development and migration processes in the urban region of Bratislava from the post-socialist transformation until the global economic crisis. Urban Geogr. 2016, 37, 1009-1029. [CrossRef]

47. Dahms, F.; McComb, J. ‘Counterurbanization', interaction and functional change in a rural amenity area-A Canadian example. J. Rural. Stud. 1999, 16, 129-146. [CrossRef]

48. Mitchell, C.J.A. Making sense of counterurbanization. J. Rural. Stud. 2004, 20, 15-34. [CrossRef]

49. Bourne, L.S. Reinventing the suburbs: Old myths and new realities. Prog. Plan. 1996, 46, 163-184. [CrossRef]

50. Szafrańska, E. Transformations of large housing estates in post-socialist city: The case of Łódź, Poland. Geogr. Pol. 2014, 87, 77-93. [CrossRef]

51. Kovács, Z.; Herfert, G. Development pathways of large housing estates in post-socialist cities: An international comparison. Hous. Stud. 2012, 27, 324-342. [CrossRef]

52. Szelenyi, I. Cities under socialism-and after. In Cities after Socialism: Urban and Regional Change and Conflict in Post-Socialist Societies; Andrusz, G., Harloe, M., Szelenyi, I., Eds.; Blackwell Publishers: Malden, MA, USA, 1996; pp. $286-317$.

53. Kok, H.; Kovacs, Z. The process of suburbanization in the agglomeration of Budapest. Neth. J. Hous. Built Environ. 1999, 14, 119-141. [CrossRef]

54. Parysek, J.J. Procesy suburbanizacji w aglomeracji poznańskiej. (Processes of suburbanization in the Poznań agglomeration). In Powiat Poznański. Jakość Przestrzeni Jakość życia; Kaczmarek, W.T., Mizgajski, A., Eds.; Bogucki Wydawnictwo Naukowe: Poznań, Poland, 2008; pp. 71-89.

55. Zborowski, A.; Raźniak, P. Suburbanizacja rezydencjalna w Polsce-ocena procesu. (Residential suburbanization in PolandEstimate of process). Studia Miej. 2013, 9, 37-50.

56. Social Housing Assistance in the Context in National Census. Pobrano z. 2016. Available online: https://stat.gov.pl/ statystyki-eksperymentalne/kapital-ludzki/socjalna-pomoc-mieszkaniowa-w-polsce-w-swietle-wynikow-narodowegospisu-powszechnego-ludnosci-i-mieszkan-2011,3,1.html (accessed on 2 November 2021).

57. Szafrańska, E. Large housing estates in a post-socialist city. Genesis, development, changes, perception. In Wielkie Osiedla Mieszkaniowe w Mieście Postsocjalistycznym. Geneza, Rozwój, Przemiany, Percepcja; UE: Łódź, Poland, 2016.

58. Parysek, J.J. Polish cities at the turn of the 21st centuries. Structural development and transformations. In Miasta Polskie na Przełomie XX i XXI Wieku. Rozwój i Przekształcenia Strukturalne; Bogucki Wydawnictwo Naukowe: Poznań, Poland, 2005.

59. Kania, K. Kształtowanie wartości gruntu przez działalność dewelopera gruntowego. Zesz. Nauk. Uniw. Ekon. W Krakowie 2010, $822,47-57$.

60. Spórna, T. The Suburbanisation Process in a Depopulation Context in the Katowice Conurbation, Poland. Environ. Socio-Econ. Stud. 2018, 1, 57-75. [CrossRef]

61. Mantey, D.; Sudra, P. Types of suburbs in post-socialist Poland and their potential for creating public spaces. Cities 2018, 88, 209-221. [CrossRef]

62. Lisowski, A. Suburbanizacja w Obszarze Metropolitalnym Warszawy. (Suburbanization in the Warsaw Metropolitan Area). In Przekształcenia Struktur Regionalnych. Aspekty Społeczne, Ekonomiczne i Przyrodnicze; Ciok, W.S., Migoń, P., Eds.; Instytut Geografii i Rozwoju Regionalnego: Wrocław, Poland, 2010; pp. 93-107.

63. Kacprzak, E.; Staszewska, S. Wpływ suburbanizacji na wiejskie struktury osadnicze. (The influence of suburbanization on rural settlement structures). Studia Miej. 2011, 3, 99-112.

64. Parysek, J.J. Urbanizacja i niektóre współczesne idee, koncepcje i modele planowania rozwoju miast. (Urbanization and some contemporary ideas, concepts and models of urban development planning). In Wspótczesne Kierunki i Wymiary Procesów Urbanizacji; Słodczyk, W.J., Śmigielska, M., Eds.; UE: Opole, Poland, 2008; pp. 11-26.

65. Falkowski, J. Geografia wsi-Próba ujęcia systemowego. (Village geography-An attempt at a systemic approach). Studia Obsz. Wiej. 2015, 37, 91-114. [CrossRef]

66. Heffner, K. Proces suburbanizacji a polityka miejska w Polsce. (The process of suburbanization and urban policy in Poland). In Miasto—Region—Gospodarka w Badaniach Geograficznych. W Stulecie Urodzin Profesora Ludwika Straszewicza; Marszał, W.T., Ed.; Wydawnictwo Uniwersytetu Łódzkiego: Łodź, Poland, 2016; pp. 75-770.

67. Sudra, P. Spatial dispersion and the concentration of buildings in an urban agglomeration-a typology proposal for the Warsaw Metropolitan Area. Environ. Socio Econ. Stud. 2020, 8, 81-96. [CrossRef]

68. Szmytkie, R. The impact of residential suburbanization on changes in the morphology of villages in the suburban area of Wrocław, Poland. Environ. Socio Econ. Stud. 2020, 8, 24-43. [CrossRef]

69. Mieszkowski, P.; Mills, E. The causes of metropolitan suburbanization. J. Econ. Perspect. 1993, 7, 135-147. [CrossRef]

70. Brueckner, J.K. Urban sprawl: Diagnosis and remedies. Int. Reg. Sci. Rev. 2000, 23, 160-171. [CrossRef] 
71. Byun, P.; Esparza, A.X. A Revisionist Model of Suburbanization and Sprawl. The Role of Political Fragmentation 2005, Growth Control, and Spillovers. J. Plan. Educ. Res. 2005, 24, 252-264. [CrossRef]

72. Sokołowski, D.; Stachowski, J. Aglomeracja Bydgosko-Toruńska w Latach 1970-1988; UMK: Torun, Poland, 1993.

73. Szymańska, D.; Chodkowska-Miszczuk, J.; Biegańska, J. Bydgosko-Toruński Obszar Funkcjonalny (Metropolitalny) w świetle wybranych wskaźników. (Bydgoszcz-Torun Functional (Metropolitan) Area in the light of selected aspects). Acta Univ. Nicolai Copernici. Ekon. 2013, 44, 319-332. [CrossRef]

74. Sokołowski, D.; Jaroszewska-Brudnicka, R.; Gierańczyk, W.; Radwańska, M.; Szyda, B. Delimitacja Bydgosko-Toruńskiego Obszaru Metropolitalnego na tle ujęć historycznych. (The historical background of the delimitation of the Bydgosko-Torunski Metropolitan Area). Acta Univ. Nicolai Copernici. Ekon. 2014, 45, 59-81. [CrossRef]

75. Development Strategy of Kujawsko-Pomorskie Voivodeship until 2030.

76. Komornicki, T.; Śleszyński, P. Typologia obszarów wiejskich pod względem powiązań funkcjonalnych i relacji miasto-wieś. (Typology of rural areas in terms of functional connections and town-village relations). Studia Obsz. Wiej. 2009, 16, 9-38.

77. Śleszyński, P.; Komornicki, T. Klasyfikacja funkcjonalna gmin Polski na potrzeby monitoringu planowania przestrzennego. (Functional classification of Polish communes for the purposes of monitoring spatial planning). Przeglad Geogr. 2016, 88, 469-488. [CrossRef]

78. Biegańska, J.; Szymańska, D. The scale and the dynamics of permanent migration in rural and peri-urban areas in Poland-some problems. Bull. Geography. Socio Econ. Ser. 2013, 21, 21-30. [CrossRef]

79. Bański, J. Problematyka definicji i zasiegu przestrzennego obszarów wiejskich i stref podmiejskich. (The problem of the definition and spatial range of rural areas and suburban zones). Acta Sci. Pol. Adm. Locorum 2012, 11, 5-15.

80. Buchecker, M.; Frick, J. The implications of urbanization for inhabitants' relationship to their residential environment. Sustainability 2020, 12, 1624. [CrossRef]

81. EEA Report, Urban Sprawl in Europe. The Ignored Challenge; European Environment Agency: Copenhagen, Denmark, 2006; No. 10 (2006).

82. CEC (Commision on European Communities). Green Paper on Territorial Cohesion. Turning Territorial Diversity into Strength. 2008. Available online: https:/ / eur-lex.europa.eu/LexUriServ/LexUriServ.do? uri=COM:2008:0616:FIN:EN:PDF (accessed on 30 October 2021).

83. EEA Report, The European Environment; State and Outlook; European Environment Agency: Copenhagen, Denmark, 2005.

84. Śleszyński, P.; Solon, J. (Eds.) Prace Planistyczne a Konflikty Przestrzenne w Gminach; (Planning works and spatial conflicts in communes); Studia KPZK PAN: Warsaw, Poland, 2010; Volume 130.

85. Raport o Ekonomicznych Stratach i Społecznych Kosztach Niekontrolowanej Urbanizacji w Polsce; Report on the Economic Losses and Social Costs of Uncontrolled Urbanization in Poland; Fundacja Rozwoju Demokracji Lo-kalnej; IGiPZ PAN: Warszawa, Poland, 2013.

86. Negatywne Skutki Chaotycznego Rozpraszania Zabudowy; Negative Effects of Chaotic Dispersal of Buildings; Ministerstwo InfraStruktury i Budownictwa; Instytut Rozwoju Miast: Kraków, Poland, 2016.

87. Smutek, J. Change of municipal finances due to suburbanization as a development challenge on the example of Poland. Bull. Geography. Socio Econ. Ser. 2017, 37, 139-149. [CrossRef] 